\title{
Density and rheological parameters of goat milk
}

\author{
Densidade e parâmetros reológicos de leite de cabra
}

\author{
Ana Lúcia GABAS ${ }^{1 *}$, Renato Alexandre Ferreira CABRAL ${ }^{2}$, \\ Carlos Augusto Fernandes de OLIVEIRA ${ }^{1}$, Javier TELIS-ROMERO ${ }^{2}$
}

\begin{abstract}
The rheological behavior and density of goat milk was studied as a function of solids concentration (10.5 to $50.0 \%)$ and temperature (273 to $331 \mathrm{k}$ ). Newtonian behavior was observed for values of total solids (TS) between 10.5 and $22.0 \%$ and temperatures from 276 to $331 \mathrm{k} \mathrm{changing}$ to pseudoplastic behavior without yield stress for TS from 25.0 to $39.4 \%$ at the same range of temperature. Goat milk with TS between 44.3 to $50.0 \%$ and temperatures of 273 to $296 \mathrm{k}$ showed yield stress in addition to pseudoplastic behavior. At 303 to $331 \mathrm{k}$ the power law model was observed again, without yield stress. The density of goat milk ranged from 991.7 to $1232.4 \mathrm{~kg} . \mathrm{m}^{-3}$.
\end{abstract}

Keywords: goat milk; physical property; rheological properties; rheometer.

\section{Resumo}

Estudou-se o comportamento reológico do leite de cabra em função da concentração (10,5 a 50,0\%) e da temperatura (273 a 331 k). O comportamento Newtoniano foi obtido para valores de sólidos totais (ST) entre 10,5 e 22,0\% e temperaturas entre 276 e $331 \mathrm{k}$, mudando para o comportamento pseudoplástico sem tensão residual para ST entre 25,0 e 39,4\% na mesma faixa de temperatura. Leite de cabra com ST entre 44,3 e 50,0\% e temperaturas entre 273 e 296 k apresentaram comportamento pseudoplástico com tensão residual. O modelo da lei da potência foi observado novamente sem tensão residual entre 303 e 331 k. Os valores experimentais de densidade do leite de cabra variaram entre 991,7 e 1232,4 kg.m ${ }^{-3}$.

Palavras-chave: leite de cabra; propriedade física; propriedades reológicas; reômetro.

\section{Introduction}

Rheological properties of fluid foods are of utmost importance for understanding the transport phenomena during unit operations (heating, cooling and freezing, pasteurizing, drying, and freeze-drying among others), as well as when designing control systems for such processes. The mathematical modeling of these operations usually consists of solving a system of coupled differential equations for heat and mass transfer, in which the rheological properties appear as an input parameter. The use of inaccurate or unsuited data may lead to an inadequate design that could unnecessarily increase production costs and even damage food product safety (GUT et al., 2005).

The range of rheology behavior of dairy products can be rather extensive depending on its composition, microstructure, and processing conditions. While milk often exhibits simple Newtonian behavior, concentrated milk shows pseudoplastic behavior; butter and sweetened condensed milk are viscoelastic, and yogurt and ice cream show thixotropic (time dependent) behavior (VÉLEZ-RUIZ; BARBOSA-CÁNOVAS, 1997).

Goat milk differs from cow or human milk by having better digestibility, higher alkalinity, increased buffering capacity, and certain therapeutic effects that may be useful in medicine and human nutrition (HAENLEIN, 2003). The good acceptability and digestibility of goat milk are important beneficial factors for its inclusion in formulated diets prescribed for children and convalescent people. In many cases, goat milk may be successfully used as substitute for cow milk in the regular diet of allergic individuals (HAENLEIN, 2003).

Although rheological and physical properties of cow milk and its dairy products have been extensively studied, there is very little information on the specific properties of goat milk, especially as a function of its solids content. In a recent review, Park (2007) reported the rheological properties of goat and sheep milk products focusing on fermented products, such as cheese and yoghurt. On the other hand, Pandya and Ghodke (2007) reviewed the available data on goat and sheep milk products other than cheeses and yoghurt, and pointed out that the technical knowledge generated from studies with cow milk is not completely applicable to products manufactured with milk from other species, such as goat and sheep milk.

The objective of the present work was to study the density and the rheological behavior of goat milk for a wide temperature range ( 276 to $331 \mathrm{k}$ ) and for total solid content between 10 and 
$50 \%$ since the commercial cow milk used in drying process in the manufacture of milk powder or sweetened concentrated milk usually has total solids between 10 to $40 \%$. The main purpose was to develop simple correlations for predicting these properties under different experimental conditions, which can routinely be found in dairy industries.

\subsection{Constitutive rheological equations}

The stress-deformation behavior of non-Newtonian inelastic fluids can be represented by the general HerschelBulkley model in Equations 1a-c, where $\sigma$ is the shear stress, $\dot{\gamma}$ is the shear rate, and $\eta$ is the apparent viscosity (STEFFE, 1996).

$$
\begin{aligned}
& \sigma=\sigma_{0}+K \dot{\gamma}^{n}, \text { for }|\sigma|>\sigma 0 \\
& \dot{\gamma}=0, \text { for }|\sigma|<\sigma 0 \\
& \eta=K \dot{\gamma}^{n-1}+\frac{\sigma_{0}}{\dot{\gamma}}
\end{aligned}
$$

The model parameters are the yield stress $(\sigma 0)$, the consistency index $(K)$, and the flow behavior index $(n)$. This model is very versatile because it is able to account for features such as viscoplasticity (the yield stress, $\sigma 0$, is minimum shear stress required to initiate flow), shear-thinning $(n<1.0)$, or shear-thickening $(n>1.0)$ (STEFFE, 1996).

Three other models can be derived from the general Herschel-Bulkley model:

1) Power Law (Ostwald-de Waele) Model: shear-thinning or shear-thickening behavior in the absence of yield stress $(\sigma 0=0.0)$, as shown by Equations $2 \mathrm{a}$ and $\mathrm{b}$.

$$
\begin{aligned}
& \sigma=K \dot{\gamma}^{n} \\
& \eta=K \dot{\gamma}^{n-1}
\end{aligned}
$$

2) Bingham Plastic Model: linear dependence between shear stress and shear rate $(n=1.0)$ with the presence of a yield stress, as shown by Equations $3 a-c$, where $\eta B$ is the plastic viscosity.

$$
\begin{aligned}
& \sigma=\sigma_{0}+\eta_{B} \dot{\gamma}, \text { for }|\sigma|>\sigma 0 \\
& \dot{\gamma}=0 \text {,for }|\sigma|<\sigma 0 \\
& \eta=\eta_{B}+\frac{\sigma_{0}}{\dot{\gamma}}
\end{aligned}
$$

3) Newtonian Model: purely viscous fluid with $\sigma 0=0.0$ and $n=1.0$, as shown by Equation 4 , where $\eta$ is the viscosity.

$$
\sigma=\eta \dot{\gamma}
$$

In foodstuffs, the most important variables that influence the rheological parameters $\sigma 0, K, n, \eta B$, or $\eta$ are temperature, composition, and processing conditions (GUNJAL; WAGHMARE, 1987; IBARZ; PAGAN; MIGUELSANZ, 1992; TELIS-ROMERO; TELIS; YAMASHITA, 1999). In order to quantify the effect of temperature on a parameter, an Arrheniustype equation, as shown by Equation 5, is frequently used, where $A 0$ is the pre-exponential factor, $E_{a}$ is the activation energy, $R$ is the universal gas constant, and $T$ is the absolute temperature (RAO; ANANTHESWARAN, 1982; VÉLEZ-RUIZ; BARBOSACÁNOVAS, 1998).

$$
\sigma_{0}, K, n, \eta_{B}, \eta=A_{0} \exp \left(\frac{E_{a}}{R T}\right)
$$

The effect of composition can be accounted for by correlating the pre-exponential factor with a specific concentration, for example the effect of the mass fat content can be modeled as a power function $A_{0}=A^{\prime} 0 . \mathrm{Xfc}$, or as an exponential function $A_{0}=A^{\prime} 0 \cdot \exp (\mathrm{c} . \mathrm{Xf})$, where $c$ is an empirical parameter (HOLDSWORTH, 1971).

\section{Material and methods}

\subsection{Sample preparation}

Fifty liters of pasteurized and homogenized whole goat milk were purchased from a local dairy plant, bulked, and concentrated in a pilot batch evaporator (Fisatom, São Paulo, Brazil), under vacuum. By using these conditions, the boiling point was kept at a low temperature $\left( \pm 68^{\circ} \mathrm{C}\right)$ during the entire process to avoid major changes in the milk constituents. The goat milk was concentrated until reaching a total solid content of $50.5 \pm 0.4 \% \mathrm{w} / \mathrm{w}$. Experimental samples containing different solids content were prepared from the same concentrated goat milk by diluting it with distilled water until reaching the concentrations of 10.5 to $50.0 \% \mathrm{w} / \mathrm{w}$. The composition of the goat milk was determined, and the main results are as follows (ASSOCIATION..., 1990): 87.6\% moisture (wet basis); $3.2 \mathrm{~g}$ protein. $100 \mathrm{~g}^{-1} ; 3.9 \mathrm{~g}$ total lipid (fat). $100 \mathrm{~g}^{-1}$; $0.8 \mathrm{~g}$ ash. $100 \mathrm{~g}^{-1}$, and $4.5 \mathrm{~g}$ carbohydrate $100 \mathrm{~g}^{-1}$ (by difference).

\subsection{Rheological behavior}

Rheological measurements were carried out in an AR 2000 rheometer (TA Instruments, Holloway Terrace, USA) using cone and plate sensor geometry (cone angle $4^{\circ}, 40 \mathrm{~mm}$ diameter) under controlled stress and temperature with the data acquisition system AR V.5.3.0. The steady shear measurements (flow curves) were performed in an extended shear rate range $\left(16-390 \mathrm{~s}^{-1}\right)$. Rheological characterization was carried out in duplicate at different sample temperatures, varying from 273 to $331 \mathrm{k}$.

Fitted functions were obtained by using the nonlinear estimation procedure of the software Statistica (STATSOFT, 1995). The suitability of the fitted functions was evaluated by the coefficient of determination $\left(\mathrm{r}^{2}\right)$ and residual analysis.

\subsection{Measurement of density}

The density of goat milk samples at different temperatures and concentrations was determined in triplicate by pycnometry (CONSTENLA; LOZANO; CRAPISTE, 1989). The samples were introduced in a $25 \mathrm{~mL}$ standard volumetric pycnometer, which was weighed using an analytical balance with uncertainty of $\pm 0.0001 \mathrm{~g}$ (Mettler, Columbus, USA). The sample temperature was changed by regulation in a thermostatic bath (model MA- 
184, Marconi, São Paulo, Brazil). The pycnometer was previously calibrated with distilled water at each studied temperature.

\section{Results and discussion}

\subsection{Flow behavior}

Rheograms of goat milk with solid content (Xs) varying from 10.5 to $50 \%$, at temperatures from 276 to $331 \mathrm{k}$, were obtained. The samples behaved as Newtonian or non-Newtonian fluids, depending on temperature and water content.

In the range of solids content between 10.5 and $22.0 \%$ and temperatures from 276 to $331 \mathrm{k}$, the rheograms showed Newtonian behavior and the viscosity, $\eta$, was calculated. The results are shown in Table 1.

As expected, viscosity increased with increasing solids content and at lower temperatures, and this correlation could be represented by Equation 6, which includes both effects. This model adjusted the experimental data with a determination coefficient $\left(\mathrm{r}^{2}\right)$ value of 0.991 including viscosities from $2.89 \times 10^{-3}$ to $25.86 \times 10^{-3}$ Pa.s.

$$
\eta=4.138 \times 10^{-7} \exp \left(\frac{E_{a}}{R T}\right) X_{s}^{2.543}
$$

Viscosities estimated with Equation 6 exhibited a good agreement with experimental values. The relative error

Table 1. Viscosities of goat milk at different solids concentrations and temperatures - Newtonian domain.

\begin{tabular}{crrrrrr}
\hline $\begin{array}{c}\text { Solids Content } \\
(\% \mathrm{w} / \mathrm{w})\end{array}$ & \multicolumn{6}{c}{ Temperature (k) } \\
\cline { 2 - 7 } & 276.2 & 286.2 & 296.7 & 307.4 & 319.0 & 331.4 \\
\hline \multicolumn{7}{c}{ Viscosity,$\eta \times 10^{3}$ (Pa.s) } \\
\hline 10.5 & 4.78 & 4.33 & 3.88 & 3.50 & 3.18 & 2.89 \\
14.8 & 8.76 & 8.01 & 7.30 & 6.32 & 6.00 & 5.48 \\
18.5 & 15.17 & 13.20 & 12.70 & 11.01 & 10.00 & 8.92 \\
22.0 & 25.86 & 22.24 & 19.83 & 18.94 & 16.61 & 14.89 \\
\hline
\end{tabular}

*Valid for shear rates between 16 to $344.2 \mathrm{~s}^{-1}$. between observed and predicted values, calculated according to Equation 7, presented an average value of $7.76 \%$ with a maximum of $22.2 \%$.

$$
\Delta \% \text { error }=100 \frac{\mid \text { observed }- \text { predicted } \mid}{\text { observed }}
$$

At higher total solids content values, the goat milk exhibited a non-Newtonian behavior. As mentioned earlier, this could be attributed mainly to the presence of fat, proteins, and other complex molecules that are produced with the concentration process. With solids content in the range of 25 to $39.4 \%$ and temperatures from 276.2 to $331.4 \mathrm{k}$, and solids content in the range of 44.3 to $50 \%$ and temperatures from 303.2 to 331.4 , the flow curves could be well fitted by the Ostwald-De Waele model; and the flow behavior index, $\mathrm{n}$, and the consistency index, $\mathrm{K}$ could be determined. These rheological parameters are presented in Table 2. The behavior index showed values varying from 0.707 to 0.989 indicating that in this range of concentration and temperature the concentrated goat milk is pseudoplastic (shear thinning) in nature. The consistency index varied from $23.7 \times 10^{-3}$ to $1115.8 \times 10^{-3} \mathrm{~Pa}$.sn and, like the Newtonian viscosity, it decreased with increasing temperature and decreasing solids content.

The flow parameters $\mathrm{K}$ and $\mathrm{n}$ could also be correlated as functions simultaneously dependent on temperature and solids content resulting in Equations 8 and 9. These functions were able to adjust the data with $r^{2}$ values higher than 0.941 . The behavior index presented relative errors Equation 7 of $1.366 \%$ on average with a maximum of $2.89 \%$, whereas the consistency index had an average error of $13.39 \%$ with a maximum of $42.35 \%$.

$$
\begin{aligned}
& n=2.034 \exp \left(\frac{A}{T}\right) X_{s}^{-0.227} \\
& K=3.16 \times 10^{-7} \exp \left(\frac{E_{a}}{R T}\right) X_{s}^{3.517}
\end{aligned}
$$

\begin{tabular}{|c|c|c|c|c|c|c|c|}
\hline \multirow{2}{*}{$\begin{array}{l}\text { Solids content } \\
(\% \mathrm{w} / \mathrm{w})\end{array}$} & \multicolumn{7}{|c|}{ Temperature $(\mathrm{k})$} \\
\hline & 276.2 & 286.2 & 296.7 & 303.2 & 307.4 & 319.0 & 331.4 \\
\hline & \multicolumn{7}{|c|}{ Consistency index ${ }^{\star}, \mathrm{K} \times 10^{3}(\mathrm{~Pa} . \mathrm{sn})$} \\
\hline 25.0 & 39.6 & 34.5 & 31.2 & & 28.0 & 26.2 & 23.7 \\
\hline 29.0 & 69.5 & 62.3 & 56.3 & & 51.2 & 47.7 & 41.8 \\
\hline 35.2 & 167.9 & 149.4 & 139.3 & & 125.8 & 115.0 & 103.9 \\
\hline 39.4 & 313.9 & 279.5 & 257.0 & & 232.8 & 209.4 & 191.0 \\
\hline 44.3 & & Viscoplastic domain & & 500.9 & 465.9 & 423.2 & 379.3 \\
\hline \multirow[t]{2}{*}{50.0} & & & & 1115.8 & 1075.6 & 1002.4 & 879.2 \\
\hline & \multicolumn{7}{|c|}{ Behavior index ${ }^{*}, \mathrm{n}$} \\
\hline 25.0 & 0.956 & 0.957 & 0.985 & & 0.974 & 0.989 & 0.989 \\
\hline 29.0 & 0.923 & 0.927 & 0.928 & & 0.936 & 0.946 & 0.948 \\
\hline 35.2 & 0.859 & 0.853 & 0.859 & & 0.873 & 0.877 & 0.884 \\
\hline 39.4 & 0.807 & 0.811 & 0.821 & & 0.830 & 0.822 & 0.843 \\
\hline 44.3 & & Viscoplastic domain & & 0.765 & 0.762 & 0.792 & 0.781 \\
\hline 50.0 & & & & 0.707 & 0.711 & 0.721 & 0.724 \\
\hline
\end{tabular}

In Equations 6 and 9, the terms corresponding to the effect of temperature on the rheological properties are similar to

Table 2. Flow parameters of goat milk at different solids concentrations and temperatures - pseudoplastic without yield stress domain.

${ }^{*}$ Valid for shear rates between 22 to $390.4 \mathrm{~s}^{-1}$. 
those of Arrhenius-type Equation 5, permitting the calculation of the activation energy for flow (Ea). The activation energies obtained for the concentrated goat milk were of 7229.9 J.mol ${ }^{-1}$ for viscosity Equation 6 and of $6723.6 \mathrm{~J} \cdot \mathrm{mol}^{-1}$ in case of the consistency index Equation 9. Their magnitudes are similar to those reported by Vélez-Ruiz and Barbosa-Cánovas (1998) for concentrated cow milk and by Tang, Munro and McCarthy (1993) for whey protein concentrated solutions. High values of activation energy mean that there is a large effect of temperature on the considered parameter (HOLDSWORTH, 1971). The dependence of temperature on the flow behavior index is also exponential, and the constant $\mathrm{A}$ in Equation 8 assumes the value of $-57.54 \mathrm{k}$. The relatively low value of the constant A indicates that the flow behavior index is nearly independent of temperature.

The presence of yield stress $(\sigma 0)$ was observed in goat milk samples with total solids adjusted at 44.3 to $50 \%$ and temperatures between 273.2 and $296.7 \mathrm{k}$, as presented in Table 3 . The behavior index showed values varying from 0.707 to 0.985 indicating that in this range of concentration and temperature the concentrated goat milk is pseudoplastic (shear thinning) in nature.

Two exponential functions were selected in order to represent the consistency index as a function of temperature for pseudoplastic behavior with yield stress. The results obtained in samples containing the highest total solids content (44.3 and $50 \%)$ are shown by Equations 10 and 11:

- For solids content of $44.3 \%$ :

$K=59.32 \exp \left(\frac{E_{a}}{R T}\right)$

with $\mathrm{r}^{2}=0.976$ and $\mathrm{E}_{\mathrm{a}}=6981.3 \mathrm{~J} . \mathrm{g} \mathrm{mol} \mathrm{m}^{-1}$

- For solids content of 50.0\%:

$K=152.87 \exp \left(\frac{E_{a}}{R T}\right)$

with $\mathrm{r}^{2}=0.979$ and $\mathrm{E}_{\mathrm{a}}=6896.9 \mathrm{~J} . \mathrm{g} \mathrm{mol} \mathrm{m}^{-1}$

The obtained correlations may be useful for the design and optimization of unit operations such as pasteurization, homogenization, spray dryer, or pumping. Additionally, experimental pressure drops data for tube flow of goat milk was used for determination of tube friction factor, which was correlated with the process conditions and compared with correlations from the literature for both Newtonian and nonNewtonian flows.

\subsection{Density}

Experimental values of density, $\rho$, shown in Table 4, presented a very strong dependence on solid content decreasing as the solvent fraction in the solution increased, as expected, since the average density of the solid constituents of the goat milk is higher than water density. The increase in temperature reduced the overall density value due to the average thermal expansion of the goat milk components. The following equation resulted as the best fit for the obtained density data
Table 3. Flow parameters of goat milk at different solids concentrations and temperatures - pseudoplastic with yield stress domain.

\begin{tabular}{|c|c|c|c|c|c|c|}
\hline \multirow{2}{*}{$\begin{array}{l}\text { Solids content } \\
(\% \mathrm{w} / \mathrm{w})\end{array}$} & \multicolumn{6}{|c|}{ Temperature (k) } \\
\hline & 273.2 & 276.2 & 281.0 & 286.2 & 291.0 & 296.7 \\
\hline & \multicolumn{6}{|c|}{ Yield stress ${ }^{*}, \tau o \times 10^{3}(\mathrm{~Pa} . \mathrm{sn})$} \\
\hline 44.3 & 918.1 & 899.4 & 923.6 & 903.1 & 878.2 & 896.9 \\
\hline \multirow[t]{2}{*}{50.0} & 2137.1 & 2140.6 & 2151.1 & 2102.2 & 2159.7 & 2111.3 \\
\hline & \multicolumn{6}{|c|}{ Consistency index ${ }^{*}, \mathrm{k} \times 10^{3}(\mathrm{~Pa} . \mathrm{sn})$} \\
\hline 44.3 & 1306.9 & 1220.8 & 1160.9 & 1120.1 & 1061.8 & 1013.0 \\
\hline \multirow[t]{2}{*}{50.0} & 3170.8 & 3070.0 & 2995.3 & 2741.9 & 2616.4 & 2521.6 \\
\hline & \multicolumn{6}{|c|}{ Behavior index*, $\mathrm{n}$} \\
\hline 44.3 & 0.771 & 0.746 & 0.748 & 0.764 & 0.762 & 0.770 \\
\hline 50.0 & 0.691 & 0.693 & 0.713 & 0.691 & 0.694 & 0.709 \\
\hline
\end{tabular}

${ }^{*}$ Valid for shear rates between 30 to $270 \mathrm{~s}^{-1}$.

Table 4. Density of goat milk at different solids concentrations and temperatures.

\begin{tabular}{lrrrrrrr}
\hline \multirow{2}{*}{$\begin{array}{c}\text { Solids content } \\
(\% \mathrm{w} / \mathrm{w})\end{array}$} & \multicolumn{7}{c}{ Temperature $(\mathrm{k})$} \\
\cline { 2 - 8 } & 273.4 & 276.0 & 290.4 & 303.2 & 307.4 & 319.0 & 331.4 \\
\cline { 2 - 8 } & 1032.5 & 1024.3 & 1029.8 & 1016.1 & 1007.1 & 1007.4 & 991.7 \\
10.5 & 1053.1 & 1049.4 & 1034.5 & 1029.8 & 1032.1 & 1018.9 & 1025.4 \\
14.8 & 1067.3 & 1065.9 & 1071.4 & 1039.2 & 1036.9 & 1023.4 & 1023.8 \\
18.5 & 1071.6 & 1060.2 & 1076.6 & 1071.8 & 1062.5 & 1053.8 & 1049.3 \\
22.0 & 1098.1 & 1089.4 & 1095.8 & 1081.7 & 1077.0 & 1073.0 & 1063.8 \\
25.0 & 1120.7 & 1116.9 & 1101.6 & 1097.0 & 1099.6 & 1085.9 & 1084.0 \\
29.0 & 1151.6 & 1150.2 & 1156.8 & 1122.6 & 1120.3 & 1103.6 & 1133.9 \\
35.2 & 1162.5 & 1153.0 & 1173.8 & 1146.3 & 1171.6 & 1137.7 & 1130.9 \\
39.4 & 1205.2 & 1195.8 & 1203.5 & 1188.7 & 1178.6 & 1180.0 & 1162.8 \\
44.3 & 1228.0 & 1232.2 & 1232.4 & 1214.5 & 1209.5 & 1191.9 & 1225.3 \\
50.0 & & & & & & & \\
\hline
\end{tabular}

of concentrated goat milk with a determination coefficient $\left(\mathrm{r}^{2}\right)$ of 0.982 . The experimental density varied from 991.7 to $1232.4 \mathrm{~kg} \cdot \mathrm{m}^{-3}$.

$\rho=639.3+349.4 \cdot \exp \left[0.0107 \cdot X_{s}\right]-0.569 \cdot T$

where $\rho$ is the density of goat milk $\left(\mathrm{kg} \cdot \mathrm{m}^{-3}\right)$; $\mathrm{X}_{\mathrm{s}}$ is the solids content (\%) and $\mathrm{T}$ is the temperature $\left({ }^{\circ} \mathrm{C}\right)$.

\section{Conclusions}

The rheological behavior of goat milk followed different models depending on temperature and the percentage of total solids. Newtonian behavior was observed at values of solids content between 10.5 and $22.0 \%$ and temperatures from 276 to $331 \mathrm{k}$. It was observed pseudoplastic behavior without yield stress for solids content between 25.0 to $39.4 \%$ and 44.3 to $50.0 \%$ at temperatures from 276 to $331 \mathrm{k}$ and 303 to $331 \mathrm{k}$, respectively. For solids content between 44.3 to $50.0 \%$ and temperatures from 273 to $296 \mathrm{k}$, a pseudoplastic behavior with yield stress was found. The Newtonian viscosity as well as the consistency index could be well correlated by functions simultaneously dependent on temperature and solids concentration. The yield stress can only be represented as a function of temperature. The results obtained for density of goat milk were well adjusted by using an exponential equation as a function of temperature and solids content. 


\section{Acknowledgement}

The authors are grateful for the financial support provided by Sao Paulo State Research Foundation, FAPESP (Proc. $\mathrm{n}^{\circ}$ 07/02688-9).

\section{References}

ASSOCIATION OF OFFICIAL ANALYTICAL CHEMISTS AOAC. Official Methods of Analysis. 15th ed. Washington: AOAC, 1990.

CONSTENlA, D. T.; LOZANO, J. E.; CRAPISTE, G. H. Thermophysical properties of clarified apple juice as a function of concentration and temperature. Journal of Food Science, v. 54, p. 663-668, 1989. http://dx.doi.org/10.1111/j.1365-2621.1989. tb04677.x

GUNJAL, B. B.; WAGHMARE, N. J. Flow characteristics of pulp juice and nectar of baneshan and neelum mangoes. Journal of Food Science and Technology, v. 24, p. 20-23, 1987.

GUT, J. A. W. et al. Continuous pasteurization of egg yolk: thermophysical properties and process simulation. Journal of Food Process Engineering, v. 28, p. 181-203, 2005. http://dx.doi. org/10.1111/j.1745-4530.2005.00416.x

HAENLEIN, G. F. W. Goat milk in human nutrition. Small Ruminant Research, v. 51, p. 155-163, 2003. http://dx.doi.org/10.1016/j. smallrumres.2003.08.010

HOLDSWORTH, S. D. Applicability of rheological models to the interpretation of flow and processing behavior of fluid food products. Journal of Texture Studies, v. 2, p. 393-418, 1971. http:// dx.doi.org/10.1111/j.1745-4603.1971.tb00589.x
IBARZ, A.; PAGAN, J.; MIGUELSANZ, R. Rheology of clarified fruit juice. II: blackcurrant juices. Journal of Food Engineering, v. 15, p. 63-73, 1992. http://dx.doi.org/10.1016/0260-8774(92)90040-D

PANDYA, A. J.; GHODKE, K. M. Goat and sheep milk products other than cheeses and yoghurt. Small Ruminant Research, v. 68, p. 193-206, 2007.http://dx.doi.org/10.1016/j.smallrumres.2006.09.007

PARK, Y. W. Rheological characteristics of goat and sheep milk. Small Ruminant Research, v. 68, p. 73-87, 2007. http://dx.doi. org/10.1016/j.smallrumres.2006.09.015

RAO, M. A.; ANANTHESWARAN, R. C. Rheology of fluids in food processing. Food Technology, v. 36, p. 116-126, 1982.

STATSOFT. STATISTICA for Windows. Computer program manual. Tulsa, 1995.

STEFFE, J. F. Rheological methods in food process engineering. East Lansing: Freeman Press, 1996. p. 418

TANG, Q.; MUNRO, P. A.; MCCARTHY, O. W. Rheology of whey protein concentrate solutions as a function of concentration, temperature, $\mathrm{pH}$ and salt concentration. Journal of Dairy Research, v. 60, p. 349-361, 1993. http://dx.doi.org/10.1017/S0022029900027692

TELIS-ROMERO, J.; TELIS, V. R. N.; YAMASHITA, F. Friction factors and rheological properties of orange juice. Journal of Food Engineering, v. 40, p. 101-106, 1999. http://dx.doi.org/10.1016/ S0260-8774(99)00045-X

VÉLEZ-RUIZ, J. F.; BARBOSA-CÁNOVAS, G. V. Effects of temperature and concentration on the rheology of concentrated milk. Transactions of the ASAE, v. 40, p. 1113-1118, 1997.

VÉLEZ-RUIZ, J. F.; BARBOSA-CÁNOVAS, G. V. Rheological properties of concentrated milk as function of concentration, temperature and storage time. Journal of Food Engineering, v. 35, p. 177-190, 1998. http://dx.doi.org/10.1016/S0260-8774(98)00019-3 